\title{
Minat Mahasiswa Fakultas Pertanian Terhadap Informasi Pertanian (Studi Kasus di Fakultas Pertanian Universitas Mulawarman)
}

\author{
Sufianti ${ }^{1}$, Tetty Wijayanti $^{2}$, dan Mursidah ${ }^{3}$ \\ 1,2,3 Fakultas Pertanian Universitas Mulawarman, Samarinda \\ ${ }^{2}$ Email: tettywijayanti_akbar@yahoo.com
}

\begin{abstract}
The diverse needs of information required by farmers, the students of agriculture needed to prepare themselves by continuing to improve their knowledge about agricultural information. The purposes of this study was to determine the needs of students of the Faculty of Agriculture on information about agriculture, how much contact the students of the Faculty of Agriculture to the source of information and liveliness of Faculty of Agriculture students in searching for information. This research had been conducted for two months starting from September 2017 until October 2017 at the Faculty of Agriculture Mulawarman University. Sampling method in this study was stratified proportional random sampling with the number of respondents is 95 students. The data collected in this research was primary data and secondary data. Methods of data retrieval was done by distributing questionnaires. Data analyzed using skoring (Likert scale). This study indicated that the interest students' for agricultural information (56.3) categories less interest, students' need for agricultural information (21.2) categories were particularly needed, contacts with information sources (15) less often categories, and activeness of information seeking (20.1) underactive categories. The conclusion of the study showed that Agricultural Faculty students were less interested in agricultural information, Agricultural Faculty students desperately needed agricultural information, Agricultural Faculty students less often made contact with information sources, and Agricultural Faculty students were less active in finded information about agriculture.
\end{abstract}

Keywords: Agriculture, Agricultural Information, College students, College students behavior, Students needs.

\begin{abstract}
ABSTRAK
Beragamnya kebutuhan informasi yang dibutuhkan petani, maka mahasiswa pertanian perlu mempersiapkan diri dengan terus meningkatkan pengetahuannya mengenai informasi pertanian. Tujuan penelitian ini untuk mengetahui kebutuhan mahasiswa Fakultas Pertanian terhadap informasi seputar pertanian, seberapa besar kontak mahasiswa Fakultas Pertanian terhadap sumber informasi dan keaktifan mahasiswa Fakultas Pertanian dalam mencari informasi. Penelitian ini telah dilaksanakan selama dua bulan dimulai dari bulan September 2017 hingga bulan Oktober 2017 di Fakultas Pertanian Universitas Mulawarman. Metode pengambilan sampel dalam penelitian ini adalah stratified proportional random sampling dengan jumlah responden adalah 95 mahasiswa. Data yang dikumpulkan dalam penelitian ini adalah data primer dan data sekunder. Metode pengambilan data dilakukan dengan cara penyebaran kuesioner. Analisis data menggunakan metode pengukuran skoring (skala Likert). Penelitian ini menunjukkan bahwa minat mahasiswa terhadap informasi pertanian $(56,3)$ kategori kurang minat, kebutuhan mahasiswa terhadap informasi pertanian $(21,2)$ kategori sangat butuh, kontak dengan sumber informasi (15) kategori kurang sering, dan keaktifan mencari informasi $(20,1)$ kategori kurang aktif. Kesimpulan penelitian menunjukkan bahwa mahasiswa Fakultas Pertanian kurang minat terhadap informasi pertanian, mahasiswa Fakultas Pertanian sangat membutuhkan informasi pertanian, mahasiswa Fakultas Pertanian kurang sering melakukan kontak dengan sumber informasi, dan mahasiswa Fakultas Pertanian kurang aktif dalam mencari informasi seputar pertanian.
\end{abstract}

Kata kunci: Mahasiswa, Pertanian, Informasi Pertanian, Perilaku mahasiswa, Kebutuhan mahasiswa. 


\section{Pendahuluan}

Dewasa ini ilmu pengetahuan dan teknologi berkembang terus dengan pesat. Bukan hanya dalam hitungan tahun, bulan, hari saja akan tetapi perkembangan itu pada jam, bahkan menit atau detik, terutama berkaitan dengan teknologi informasi dan komunikasi yang ditunjang oleh teknologi elektronika, dan berpengaruh kepada segala bidang kehidupan termasuk bidang pertanian.

Abad kedua puluh dianggap sebagai era perkembangan ilmu pengetahuan, informasi, globalisasi, dan teknologi. Dampak dari perkembangan tersebut yaitu pada kehidupan masyarakat. Hal ini dikarenakan semua aspek kehidupan tidak lepas dari digerakkan oleh pengetahuan dan teknologi. Masa kini dan masa yang akan datang masyarakat dituntut melek teknologi (technology literacy) dikarenakan akan berperan dalam kehidupannya. Memilih, merancang, membuat dan menggunakan berbagai hasil rekayasa teknologi mampu dilakukan jika masyarakat mengerti akan teknologi. Pertanian merupakan bagian dari masyarakat tersebut, dan di dalam pertanian itu pula terdapat mahasiswa pertanian.

Ditemukannya inovasi-inovasi baru oleh para peneliti baik yang berada di dalam negeri maupun di luar negeri dikarenakan sampai saat ini terjadi peningkatan pada perkembangan teknologi pertanian. Lambannya diseminasi informasi teknologi pertanian para petani merupakan salah satu masalah yang dihadapi dalam pertanian di negara kita (Prihandoyo, 2014). Hasil penelitian oleh Windi Baskoro Prihandoyo yang berjudul Efektivitas Diseminasi Informasi Pertanian Melalui Media Telepon Genggam Pada Petani Sayuran Di Kecamatan Pacet Kabupaten Cianjur (2014) menyatakan bahwa secara umum karakteristik responden, aksesibilitas informasi dan intensitas komunikasi berhubungan nyata dengan efektivitas diseminasi informasi di bidang pertanian melalui media telepon genggam dan terdapat hubungan yang nyata dan positif antara masing-masing dari ketiga peubah bebas: karakteristik, aksesibilitas informasi dan intensitas komunikasi petani sayuran yang menggunakan telepon genggam.

Beragam informasi diperlukan oleh petani untuk mendukung usahataninya. Bukan hanya informasi praktis mengenai teknologi produksi tanaman saja, akan tetapi informasi yang dibutuhkan adalah mengenai pascapanen (pengolahan, penyimpanan, dan penanganan) serta pemasaran. Petani dalam pengelolaan usahataninya memerlukan pengetahuan dan informasi mengenai hasil penelitian, pengalaman dari petani lain, situasi mutakhir yang terjadi di pasar input dan produk pertanian, serta kebijakan pemerintah (Mulyandari dan Ananto, 2005). 
Hasil penelitan dalam jurnal yang berjudul Pemanfaatan Teknologi Informasi Untuk Meningkatkan Pemasaran Hasil Pertanian di Desa Curut Kecamatan Penawangan Kabupaten Grobogan Jawa Tengah oleh MG. Catur Yuantari, Arif Kurniadi dan Ngatindriatun, bahwa sebagian besar 55,56\% hasil pertanian petani sudah dibeli oleh tengkulak sebelum waktu panen. Petani yang tidak tahu informasi penjualan langsung menyerahkan hasil tanamnya kepada tengkulak, sehingga bila panennya baik banyak sekali petani yang dirugikan bila hasil tanamnya dibeli oleh tengkulak. Namun terdapat beberapa petani yang langsung menjual hasil tanamnya di pasar induk Jakarta dan Bandung. Bila petani yang tidak berpengalaman menjual di pasar akan sama saja hasilnya walapun lebih untung sedikit. Bila terlalu lama di pasar buah akan busuk dan petani yang menanggung kerugiannya. Tingkat pengetahuan petani tentang sistem penjualan dengan menggunakan internet $100 \%$ tidak pernah tahu dan tidak menggunakannya, bahkan hanya $9,26 \%$ yang bisa menggunakan internet. Terdapat $5,6 \%$ petani yang menggunakan internet untuk penjualan. Perkembangan teknologi dan pengetahuan di segala bidang dari tahun ke tahun kian meningkat, namun tidak semua orang dapat menikmatinya. Salah satunya pemanfaatan internet oleh petani. Internet telah berkembang pesat dan hampir digunakan oleh semua orang untuk mempermudah pekerjaannya.

Melihat beragamnya kebutuhan informasi yang dibutuhkan petani, maka mahasiswa pertanian perlu mempersiapkan diri dengan terus meningkatkan pengetahuannya mengenai informasi pertanian. Kemampuan mahasiswa pertanian untuk memenuhi kebutuhan informasi pertanian dapat didongkrak jika mahasiswa pertanian dapat menunjukkan kemampuannya sesuai dengan tuntunan, kebutuhan serta potensi masyarakat. Disini mahasiswa pertanian dituntut untuk dapat terus meningkatkan kualifikasinya. Hal ini berarti bahwa mahasiswa diharuskan untuk terus belajar dan aktif mencari informasi.

Berdasarkan latar belakang di atas dapat dikemukakan beberapa permasalahan yaitu: (1) Bagaimana minat mahasiswa Fakultas Pertanian terhadap informasi pertanian, (2) Bagaimana kebutuhan mahasiswa Fakultas Pertanian terhadap informasi seputar pertanian, (3) Bagaimana kontak mahasiswa Fakultas Pertanian terhadap sumber informasi, (4) Bagaimana keaktifan mahasiswa Fakultas Pertanian dalam mencari informasi seputar pertanian. Adapun tujuan penelitian ini yaitu: (1) Mengetahui minat mahasiswa Fakultas Pertanian terhadap informasi pertanian, (2) Mengetahui kebutuhan mahasiswa Fakultas Pertanian terhadap informasi seputar pertanian, (3) Mengetahui seberapa sering kontak mahasiswa Fakultas Pertanian terhadap sumber informasi, (4) Mengetahui keaktifan mahasiswa Fakultas Pertanian dalam mencari informasi seputar pertanian. Manfaat dari penelitian ini diantaranya: (1) Sebagai bahan masukan bagi peneliti, mahasiswa Fakultas Pertanian dalam rangka meningkatkan pengetahuan mengenai 
pentingnya informasi pertanian, (2) Sumbangan pemikiran dalam pengembangan ilmu pengetahuan khususnya mengenai mahasiswa Fakultas Pertanian terhadap informasi pertanian, (3) Sebagai bahan masukan bagi instansi yang berkompeten untuk menyediakan informasi yang tepat guna bagi mahasiswa Fakultas Pertanian, (4) Referensi pembanding dan konsep dalam kepentingan akademik dan stimulant bagi peneliti selanjutnya.

\section{Metode Penelitian}

\section{Metode Pengambilan Data}

Data primer adalah data yang diperoleh/dikumpulkan sendiri oleh peneliti dengan melakukan pengamatan langsung terhadap objek yang akan diteliti, melalui penyebaran kuesioner kepada responden. Data sekunder diperoleh dari studi literatur dan pihak lainnya yang ada hubungannya dengan penelitian ini diantaranya Kantor Akademik Fakultas Pertanian serta studi pustaka dari penelitian terdahulu.

\section{Metode Pengambilan Sampel}

Populasi dalam penelitian ini adalah mahasiswa Fakultas Pertanian yang berjumlah 1900 (seribu sembilan ratus) orang. Untuk menentukan besarnya ukuran sampel maka dilakukan dengan menggunakan rumus Slovin (Silalahi, 2015); dan penarikan sampel menggunakan Stratified proportional random sampling yaitu pengambilan sampel dari populasi yang terdiri dari strata yang mempunyai susunan bertingkat dalam hal ini adalah mahasiswa Fakultas Pertanian angkatan tahun 2013, 2014, 2015 dan 2016 yang terdiri dari empat jurusan yaitu Agribisnis (AGB), Agroekoteknologi (AGT), Teknologi Hasil Pertanian (THP), dan Peternakan (PTK) yang ditentukan oleh peneliti.

\section{Metode Analisis Data}

Metode analisis data pada penelitian ini menggunakan metode pengukuran skoring (skala likert). Pengukuran indikator-indikator yang telah dijabarkan disusun dalam bentuk kuesioner. Setiap pertanyaan diberikan skor sesuai dengan pilihan responden. Pilihan a diberikan skor 3 (tiga) sedangkan b dan c diberikan skor 2 (dua) dan 1 (satu), (Sugiyono,2010). Rincian skor minimum dan maksimum dari 3 (tiga) komponen mengenai minat mahasiswa Fakultas Pertanian terhadap informasi pertanian (studi kasus di Fakultas Pertanian Universitas Mulawarman) dapat dilihat pada Tabel 1.

Tabel 1. Skor Penilaian Minat Mahasiswa Fakultas Pertanian Terhadap Informasi Pertanian

\begin{tabular}{clcc}
\hline No & $\begin{array}{c}\text { Skor Penilaian minat mahasiswa Fakultas } \\
\text { Pertanian terhadap informasi pertanian. }\end{array}$ & Skor Minimum & Skor Maksimum \\
\hline 1 & Tingkat kebutuhan terhadap informasi pertanian. & 8 & 24 \\
2 & Kontak dengan sumber informasi. & 7 & 21 \\
3 & Keaktifan mencari informasi. & 9 & 27 \\
\hline & Total & $\mathbf{2 4}$ & $\mathbf{7 2}$
\end{tabular}

Sumber : Mardikanto, 2010

Agar diperoleh pengertian apa yang lebih jelas mengenai apa yang akan diteliti, maka definisi variabel dan pengukurannya dapat dijabarkan sebagai berikut : 
ISSN 2354-7251 (print)

1. Minat pemanfatan informasi didefinisikan sebagai tingkat keinginan atau niat pemakai menggunakan sistem secara terus menerus dengan asumsi bahwa mereka mempunyai akses terhadap informasi.

2. Tingkat kebutuhan terhadap informasi pertanian adalah segala sesuatu yang disampaikan, dapat berupa berita, kata, atau pengetahuan.

3. Kontak dengan sumber informasi adalah intensitas atau tingkat keseringan mahasiswa dalam memanfaatkan media informasi.

4. Keaktifan mencari sumber informasi adalah usaha yang dilakukan karena minat atau keinginan tahu secara pribadi terhadap sumber-sumber informasi.

Minat mahasiswa Fakultas Pertanian terhadap informasi pertanian dibedakan menjadi tiga kelas yaitu:

1. Berdasarkan minat mahasiswa terhadap informasi pertanian dibagi 3 (tiga) kategori yaitu tidak minat, kurang minat dan sangat minat.

2. Berdasarkan tingkat kebutuhan terhadap informasi pertanian dibagi 3 (tiga) kategori yaitu tidak butuh, kurang butuh dan sangat butuh.

3. Berdasarkan kontak dengan sumber informasi dibagi 3 (tiga) kategori yaitu tidak pernah, kurang sering, dan sangat sering.

4. Berdasarkan keaktifan mencari informasi dibagi 3 (tiga) kategori yaitu tidak aktif, kurang aktif, dan sangat aktif.

Menurut Suparman (1995), interval kelas dapat ditentukan menggunakan rumus sebagai berikut :

$$
C=\frac{x n-x i}{K}
$$

Keterangan :

$\mathrm{C} \quad=$ Interval kelas

$\mathrm{xn} \quad=$ Skor maksimum

$\mathrm{xi} \quad=$ Skor minimum

$\mathrm{K}=$ Jumlah kelas

Berdasarkan rumus diatas maka dapat diketahui interval dari setiap kelas yaitu :

1. Interval minat mahasiswa terhadap informasi pertanian

$$
C=\frac{x n-x i}{K}=\frac{72-24}{3}=16
$$

2. Interval tingkat kebutuhan terhadap informasi pertanian adalah :

$$
C=\frac{x n-x i}{K}=\frac{24-8}{3}=5,3
$$

3. Interval kontak dengan sumber informasi adalah :

$$
C=\frac{x n-x i}{K}=\frac{21-7}{3}=4,7
$$

4. Interval keaktifan mencari informasi adalah :

$$
C=\frac{x n-x i}{K}=\frac{27-9}{3}=6
$$


Berdasarkan hasil perhitungan di atas dapat digunakan untuk membuat kategori minat terhadap informasi pertanian, tingkat kebutuhan terhadap informasi pertanian, kontak dengan sumber informasi, dan keaktifan mencari informasi.

Tabel 2. Minat Terhadap Informasi Pertanian

\begin{tabular}{clc}
\hline No & Interval Kelas & Tingkat minat terhadap informasi pertanian \\
\hline 1 & $24-40$ & Tidak minat \\
2 & $41-57$ & Kurang minat \\
3 & $58-74$ & Sangat minat \\
\hline Sumber : Data primer (diolah) 2017 &
\end{tabular}

Tabel 3. Tingkat Kebutuhan Terhadap Informasi Pertanian

\begin{tabular}{clc}
\hline No & Interval Kelas & Tingkat kebutuhan terhadap informasi pertanian \\
\hline 1 & $8-13,3$ & Tidak butuh \\
2 & $13,4-18,7$ & Kurang butuh \\
3 & $18.8-24,1$ & Sangat butuh \\
\hline
\end{tabular}

Sumber : Data primer (diolah) 2017

Tabel 4. Kontak dengan Sumber Informasi

\begin{tabular}{clc}
\hline No & Interval Kelas & Tingkat kontak dengan sumber informasi \\
\hline 1 & $7-11,7$ & Tidak pernah \\
2 & $11,8-16,5$ & Kurang sering \\
3 & $16,6-21,3$ & Sangat sering \\
\hline
\end{tabular}

Tabel 5. Keaktifan Mencari Informasi

\begin{tabular}{clc}
\hline No & Interval Kelas & Tingkat kontak dengan sumber informasi \\
\hline 1 & $9-15$ & Tidak aktif \\
2 & $15,1-21,1$ & Kurang aktif \\
3 & $21,2-27,2$ & Sangat aktif \\
\hline
\end{tabular}

Sumber : Data primer (diolah) 2017

\section{Hasil dan Pembahasan}

\section{Minat mahasiswa terhadap informasi pertanian}

Tabel 6. Rincian Skor Minat Mahasiswa Terhadap Informasi Pertanian

\begin{tabular}{lccc}
\hline No & $\begin{array}{c}\text { Interval Kelas Indikator Minat Mahasiswa } \\
\text { terhadap Informasi Pertanian }\end{array}$ & $\begin{array}{c}\text { Jumlah Responden } \\
(\text { Jiwa })\end{array}$ & $\begin{array}{c}\text { Persentase } \\
(\%)\end{array}$ \\
\hline 1 & Tidak minat & 1 & 1 \\
2 & Kurang minat & 52 & 54,7 \\
3 & Sangat minat & 42 & 44,3 \\
\hline Jumlah & & $\mathbf{9 5}$ & $\mathbf{1 0 0}$ \\
Total Skor & & $\mathbf{5 3 5 1}$ & \\
Rata-rata Skor & & $\mathbf{5 6 , 3}$ & \\
Kategori & Kurang Minat & \\
\hline
\end{tabular}

Sumber : Data Primer (diolah), 2017

Berdasarkan Tabel 6 diketahui bahwa dari 95 responden, 1 (satu) responden menyatakan bahwa tidak minat terhadap informasi pertanian dengan presentase 1\%, 52 (lima puluh dua) responden menyatakan bahwa kurang minat terhadap informasi pertanian dengan presentase $54,7 \%$ dan 42 (empat puluh dua) responden menyatakan sangat minat dengan presentase $44,3 \%$. Dari hasil penelitian dapat disimpulkan bahwa mahasiswa Fakultas Pertanian kurang minat terhadap informasi pertanian dengan presentase $56,3 \%$.

\section{Tingkat Kebutuhan Terhadap Informasi Pertanian}


Berdasarkan Tabel 7 diketahui bahwa dari 95 responden, 7 (tujuh) responden menyatakan bahwa kurang butuh terhadap informasi pertanian dengan presentase $7,37 \%$, sedangkan 88 (delapan puluh delapan) responden menyatakan bahwa sangat butuh terhadap informasi pertanian dengan presentase 93,63\%. Dari hasil penelitian mengenai Tiingkat kebutuhan mahasiswa Fakultas Pertanian terhadap informasi pertanian dapat dinyatakan tingginya tingkat kebutuhan mahasiswa untuk mengetahui berbagai macam informasi pertanian dengan presentase $21,2 \%$.

Tabel 7. Rincian Skor Tingkat Kebutuhan Terhadap Informasi Pertanian

\begin{tabular}{lccc}
\hline No & $\begin{array}{c}\text { Interval Kelas Indikator Tingkat Kebutuhan } \\
\text { Terhadap Informasi Pertanian }\end{array}$ & $\begin{array}{c}\text { Jumlah } \\
\text { Responden(Jiwa) }\end{array}$ & $\begin{array}{c}\text { Persentase } \\
(\%)\end{array}$ \\
\hline 1 & Tidak Butuh & 0 & 0 \\
2 & Kurang Butuh & 7 & 7,37 \\
3 & Sangat Butuh & 88 & 93,63 \\
\hline Jumlah & 95 & $\mathbf{1 0 0}$ \\
Total Skor & $\mathbf{2 0 1 6}$ & \\
Rata-rata Skor & $\mathbf{2 1 , 2}$ & \\
Kategori & Sangat Butuh & \\
\hline Sumber : Data Primer (diolah), 2017 & &
\end{tabular}

\section{Kontak dengan Sumber Informasi}

Berdasarkan Tabel 8 diketahui bahwa dari 95 responden, 5 (lima) responden menyatakan bahwa tidak pernah melakukan kontak dengan sumber informasi dengan presentase 5,2\%, 62 (enam puluh dua) responden menyatakan kurang sering melakukan kontak dengan sumber informasi dengan presentase mencapai 65,3\%, dan 28 (dua puluh delapan) responden menyatakan sangat sering melakukan kontak dengan sumber informasi dengan presentase mencapai 29,5\%. Dari hasil penelitian mengenai kontak mahasiswa Fakultas Pertanian terhadap informasi pertanian dapat dinyatakan bahwa mahasiswa tidak begitu sering melakukan kontak dengan sumber informasi atau dalam penelitian ini dinyatakan dalam kategori kurang sering dengan presentase $15 \%$.

Tabel 8. Rincian Skor Indikator Kontak dengan Sumber Informasi

\begin{tabular}{clcc}
\hline No & $\begin{array}{c}\text { Interval Kelas Indikator Kontak } \\
\text { dengan Sumber Informasi }\end{array}$ & $\begin{array}{c}\text { Jumlah Responden } \\
\text { (Jiwa) }\end{array}$ & $\begin{array}{c}\text { Persentase } \\
\text { (\%) }\end{array}$ \\
\hline 1 & Tidak Pernah & 5 & 5,2 \\
2 & Kurang Sering & 62 & 65,3 \\
3 & Sangat Sering & 28 & 29,5 \\
\hline Jumlah & $\mathbf{9 5}$ & $\mathbf{1 0 0}$ \\
Total Skor & $\mathbf{1 4 2 9}$ & \\
Rata-rata Skor & $\mathbf{1 5}$ & \\
Kategori & Kurang sering \\
\hline
\end{tabular}

Sumber : Data Primer (diolah), 2017

\section{Keaktifan Mencari Informasi}

Berdasarkan Tabel 9 diketahui bahwa dari 95 responden, 6 (enam) responden menyatakan bahwa tidak aktif mencari informasi dengan presentase 6,3\%, 59 (lima puluh sembilan) responden menyatakan kurang aktif mencari informasi dengan presentase mencapai $62,1 \%$, dan 30 (tiga puluh) responden menyatakan sangat aktif mencari informasi 
dengan presentase mencapai 31,6\%. Dari hasil penelitian mengenai keaktifan mahasiswa Fakultas Pertanian dalam mencari informasi pertanian dapat dinyatakan bahwa mahasiswa kurang aktif dengan presentase $20,1 \%$.

Tabel 9. Rincian Skor Indikator Keaktifan Mencari Informasi

\begin{tabular}{lccc}
\multicolumn{3}{c}{ Tabel 9. Rincian Skor Indikator Keaktifan Mencari Informasi } \\
\hline No & $\begin{array}{c}\text { Interval Kelas Indikator } \\
\text { Keaktifan Mencari Informasi }\end{array}$ & $\begin{array}{c}\text { Jumlah Responden } \\
\text { (Jiwa) }\end{array}$ & $\begin{array}{c}\text { Persentase } \\
(\%)\end{array}$ \\
\hline 1 & Tidak Aktif & 6 & 6,3 \\
2 & Kurang Aktif & 59 & 62,1 \\
3 & Sangat Aktif & 30 & 31,6 \\
\hline Jumlah & & $\mathbf{9 5}$ & $\mathbf{1 0 0}$ \\
Total Skor & $\mathbf{1 9 0 6}$ & \\
Rata-rata Skor & $\mathbf{2 0 , 1}$ & \\
Kategori & Kurang Aktif & \\
Sumber : Data Primer (diolah), 2017 & &
\end{tabular}

\section{Minat mahasiswa terhadap informasi pertanian}

Tingkat keinginan atau niat pemakai menggunakan sistem secara terus menerus dengan berasumsi bahwa mereka mempunyai akses terhadap informasi merupakan definisi dari minat pemanfaatan informasi. Menurut Slameto (2010) minat yaitu rasa lebih suka dan rasa ketertarikan pada suatu hal atau aktivitas tanpa ada yang menyuruh. Pada dasarnya minat dapat diartikan sebagai penerimaan akan suatu hubungan antara diri sendiri dengan sesuatu di luar diri. Semakin besar minat jika semakin kuat atau dekat hubungan tersebut.

Tingkat kebutuhan mahasiswa Fakultas Pertanian terhadap Informasi pertanian berbeda dengan usaha yang dilakukan untuk memenuhi kebutuhan informasi karena mahasiswa Fakultas Pertanian kurang sering melakukan kontak dengan sumber informasi dan kurang aktif dalam mencari informasi sehingga minat mahasiswa Fakultas Pertanian terhadap informasi pertanian masuk dalam ketegori kurang minat dikarenakan kurangnya motivasi dalam diri mahasiswa untuk memenuhi kebutuhan informasi pertanian. Motivasi dari luar berupa tugas kuliah mampu mendorong mahasiswa untuk mencari informasi pertanian namun terkadang mahasiswa kesulitan dalam menemukan informasi pertanian yang sesuai dengan kebutuhan.

Menurut Ahcmad dan Silalahi (2015), rendahnya minat mahasiswa Non Pendas Kota Kupang mengikuti tuton, disebabkan kurangnya penjelasan atau UT kurang gencar menginformasikan manfaat layanan bantuan tuton kepada mahasiswa. Selain itu, yang paling mendasar adalah mahasiswa tidak mempunyai keterampilan mengoperasi komputer dan mengakses internet, juga karena masalah kekurangan dalam kemampuan finansial. Mahasiswa akan berminat mengikuti layanan bantuan belajar tuton UT, apabila mahasiswa diberikan motivasi mengikuti tuton dengan jalan memberikan sosialisasi tentang tuton, sehingga mahasiswa merasa senang bahwa tuton itu adalah suatu kebutuhan dalam membantu mahasiswa dalam belajar. Selain itu, mahasiswa mengharapkan agar UT 
menyiapkan fasilitas komputer dan fasilitasi dalam berlatih mengoperasikan komputer dan mengakses. Selain itu, mahasiswa mengharapkan dalam penyelenggaraan tuton menarik dan ditingkatkan.

\section{Tingkat Kebutuhan terhadap Informasi Pertanian}

Segala sesuatu yang disampaikan baik berita, kata, ataupun pengetahuan merupakan tingkat kebutuhan terhadap informasi pertanian yang termaksud dalam penelitian ini. Davis (2009) mendefinisikan informasi adalah hasil dari olahan sebuah data yang memberikan pemahaman, wawasan, kesimpulan, keputusan, konfirmasi atau rekomendasi bagi si penerima. Informasi tersebut dapat berupa laporan, analisis, data yang terorganisir dalam output yang dapat dimengerti, respon verbal, grafik, gambar atau video.

Hal yang sangat penting didalam pengambilan sebuah keputusan atau kesimpulan adalah informasi. Hasil yang diberikan kurang memuaskan atau kurang akurat biasanya disebabkan oleh suatu keputusan atau kesimpulan yang tidak didukung informasi yang cukup. Suatu rekaman fenomena yang diamati, atau bisa juga berupa putusan-putusan yang dibuat seseorang merupakan informasi. Informasi dapat diartikan juga sebagai suatu kejadian atau suatu gejala alam yang diamati seseorang kemudian dapat direkam baik dalam pikiran orang yang mengamati atau juga dapat terekam di dalam sebuah alat yang dapat menyimpan sebuah fenomena. Kemudian dapat dijelaskan bahwa sebuah keputusan yang dibuat seseorang dari hasil pengamatan juga merupakan informasi.

Mahasiswa pertanian menyatakan tertarik dengan informasi seputar pertanian, namun rata-rata menyatakan bahwa informasi yang diterima kurang sesuai dengan yang mereka butuhkan, sehingga mereka kurang memahami informasi pertanian. Informasi pertanian sangat memberi manfaat terhadap mahasiswa Fakultas Pertanian sehingga dapat membantu mahasiswa dalam kehidupan sehari-hari berupa pengaplikasian ilmu pertanian namun mahasiswa kurang berusaha untuk mendapatkan informasi secara mutakhir karena kurang seringnya mahasiswa melakukan kontak terhadap sumber informasi dan mahasiswa kurang aktif dalam mencari informasi pertanian. Dari hasil penelitian Mahasiswa Fakultas pertanian rata-rata menyatakan berusaha mengembangkan diri menjadi mahasiswa/i yang profesional dibidangnya masing-masing.

Hubungan positif yang nyata dengan tingkat manfaat yang dirasakan responden terhadap informasi yang diakses dimiliki oleh tingkat kebutuhan akan informasi pertanian. Hal ini adalah hubungan yang logis dikarenakan semakin tinggi tingkat kebutuhan informasi responden, semakin tinggi juga tingkat manfaat yang dirasakan responden terhadap informasi yang diperoleh dari berbagai sumber informasi, baik melalui media siber, media cetak maupun media elektronis. 
Menurut Andriaty dkk (2011), bahwa Informasi yang sangat dibutuhkan oleh petani yaitu berkaitan dengan teknologi produksi, diikuti informasi pemasaran dan pascapanen, akan tetapi masih belum terpenuhi sehingga para petani menggunakan pertemuan, media cetak, dan media elektronis untuk mengakses informasi. Pertemuan diikuti oleh media elektronis kemudian media cetak merupakan media yang paling sering diakses. Secara umum kemudahan akses ke media komunikasi berbanding lurus dengan tingkat akses. Mendorong minat terhadap inovasi dan mencoba inovasi, meningkatkan akan pemahaman, dan memotivasi mereka untuk menerapkannya adalah manfaat dari informasi yang diakses. Tingkat akses ke sumber informasi pertanian berhubungan nyata terhadap umur. Tingkat kekosmopolitan dan tingkat manfaat informasi merupakan faktor yang dipengaruhi akses terhadap informasi untuk daerah yang mudah mengakses informasi (Magelang dan Malang) dan yang sulit mengakses informasi (Banjarnegara dan Pacitan).

\section{Kontak dengan Sumber Informasi}

Pada penelitian ini, kontak dengan sumber informasi yang dimaksud adalah intensitas atau tingkat keseringan mahasiswa dalam memanfaatkan media informasi. Pengoptimalan kegiatan diseminasi (penyebarluasan informasi) hasil penelitian dan teknologi pertanian melalui berbagai media, baik melalui media cetak (buku, prosiding, jurnal, brosur, leaflet atau folder dan poster), media elektronik (televisi, radio, CD, surat elektronik, dan internet) maupun melalui tatap muka, berupa seminar, lokakarya, workshop atau apresiasi dan advokasi merupakan tantangan yang harus ditanggapi secara sistematis dari terbukanya pasar global dan peningkatan selera konsumen ke arah mutu produk pertanian yang lebih tinggi (Setiabudi, 2004).

Tabel 10. Rincian Jumlah Responden Pengguna Media Siber dalam Mencari Informasi

\begin{tabular}{lll}
\hline \multirow{2}{*}{ Jenis media siber (Cyber media) } & Website & 57 responden \\
& Media social & 26 responden \\
& Blog & 12 responden \\
\hline $\begin{array}{l}\text { Waktu yang digunakan dalam mencari } \\
\text { informasi }\end{array}$ & Kurang dari 1 jam $/ \mathrm{minggu}$ & 42 responden \\
& Kurang dari 3 jam $/ \mathrm{minggu}$ & 34 responden \\
& Kurang dari $7 \mathrm{jam} / \mathrm{minggu}$ & 19 responden \\
\hline
\end{tabular}

Sumber : Data Primer (diolah), 2017

Media informasi yang lebih sering digunakan mahasiswa dalam mencari informasi dari 95 responden berdasarkan kuesioner penelitian adalah media siber (cyber media) sebanyak 54 responden, kemudian media elektronik (electronic media) sebanyak 34 responden lalu media cetak (printed media) sebanyak 7 responden. Media siber (cyber media) yang digunakan mahasiswa Fakultas pertanian dari 95 responden adalah website sebanyak 57 responden, media sosial sebanyak 26 responden kemudian 12 responden menggunakan blog sebagai media yang sering digunakan dalam mencari informasi. Waktu yang digunakan dalam mencari informasi pertanian melalui media siber (cyber media) adalah kurang dari 1 jam/minggu oleh 42 responden, kurang dari 3 jam/minggu oleh 34 
ISSN 2354-7251 (print)

responden dan kurang dari 7 jam/minggu oleh 19 responden. Lebih jelasnya dapat dilihat pada Tabel 10.

Media elektronik (electronic media) yang digunakan mahasiswa Fakultas Pertanian dalam mencari informasi adalah televisi sebanyak 87 responden, kemudian melalui film sebanyak 5 responden dan 3 responden menyatakan menggunakan media elekronik radio. Waktu yang digunakan dalam mencari informasi pertanian melalui media elektronik (electronic media) adalah kurang dari 1 jam/minggu oleh 46 responden, kurang dari 3 jam/minggu oleh 31 responden dan kurang dari 7 jam/minggu oleh 18 responden. Lebih jelasnya dapat dilihat pada Tabel 11.

Tabel 11. Rincian Jumlah Responden Pengguna Media Elektronik Mencari Informasi

\begin{tabular}{lll}
\hline Jenis media elektronik(Electronic media) & Televisi & 87 responden \\
& Film & 5 responden \\
& Radio & 46 responden \\
\hline \multirow{2}{*}{$\begin{array}{l}\text { Waktu yang digunakan dalam mencari } \\
\text { informasi }\end{array}$} & Kurang dari 1 jam/minggu & \\
& Kurang dari 3 jam/minggu & 31 responden \\
& Kurang dari 7 jam/minggu & 18 responden \\
\hline
\end{tabular}

Sumber : Data Primer (diolah), 2017

Tabel 12. Rincian Jumlah Responden Pengguna Media Cetak dalam Mencari Informasi

\begin{tabular}{lll}
\hline \multirow{2}{*}{ Jenis media cetak (Printed media) } & Surat kabar & 66 responden \\
& Majalah & 22 responden \\
& Tabloid & 7 responden \\
\hline $\begin{array}{l}\text { Waktu yang digunakan dalam mencari } \\
\text { informasi }\end{array}$ & Kurang dari 1 jam/minggu & 65 responden \\
& Kurang dari 3 jam/minggu & 21 responden \\
& Kurang dari 7 jam/minggu & 18 responden \\
\hline
\end{tabular}

Sumber : Data Primer (diolah), 2017

Berdasarkan Tabel 12 diketahui bahwa media cetak (printed media) yang digunakan mahasiswa Fakultas Pertanian dari 95 responden, 66 responden menggunakan surat kabar, 22 responden menggunakan majalah dan 7 responden menggunakan tabloid. Waktu yang digunakan dalam mencari informasi pertanian melalui media cetak (printed media) adalah kurang dari 1 jam/minggu oleh 65 responden, kurang dari 3 jam/minggu oleh 21 responden dan kurang dari 7 jam/minggu oleh 18 responden.

\section{Keaktifan Mencari Informasi}

Keaktifan mencari sumber informasi dalam penelitian ini adalah usaha yang dilakukan karena minat atau keingintahuan secara pribadi terhadap sumber-sumber informasi. Upaya yang dilakukan oleh seseorang untuk memenuhi kebutuhannya merupakan perilaku pencarian informasi. Tindakan yang dilakukan oleh pengguna dalam memenuhi kebutuhan informasi adalah perilaku pencarian informasi. Setiap orang berbeda dalam tindakannya. Cara penggunaan dalam mencari informasi dipengaruhi oleh beberapa faktor yaitu tingkat kebutuhan yang berbeda maupun dari kemampuan pengguna. Kebutuhan informasi erat kaitannya terhadap perilaku pencarian informasi. Terdapat 
beberapa informasi yang ditemukan tanpa melakukan pencarian, akan tetapi ketika seseorang membutuhkan informasi dengan sendirinya akan tercipta sebuah perilaku untuk mencari informasi yang dibutuhkan (Wilson,2000).

Mahasiswa Fakultas Pertanian atau dalam penelitian ini adalah responden menyatakan kurang sering diadakan diskusi seputar pertanian dan meskipun ada diskusi seputar pertanian responden rata-rata menyatakan hanya terkadang ikut serta itupun jika mendapatkan informasi acara. Mahasiswa atau dalam penelitian ini responden menyatakan terkadang berbagi ilmu seputar pertanian kepada orang lain, dan rata-rata responden menyatakan menyiapkan diri untuk mengembangkan lebih lanjut informasi yang didapatkan. Motivasi dalam mencari informasi seputar pertanian berasal dari diri mahasiswa / responden dan terkadang berasal dari luar. Responden menyatakan terkadang memiliki inovasi dibidang pertanian namun tidak menyebutkan inovasi yang dimaksudkan. Adapun ketersediaan informasi pertanian kurang sesuai dan agak sulit untuk diakses.

Menurut Adhyani (2008) bahwa keaktifan mencari informasi melalui tatap muka responden masih rendah, baik dengan penyuluh, pembudidaya lain, peneliti, wakil perusahaan maupun dengan kelompok budidaya ikan hias. Keaktifan mencari informasi melalui media juga masih rendah. Ditandai dengan rendahnya tingkat keaktifan mencari informasi rensponden melalui media TV, majalah dan leaflet. Tingkat perilaku agribisnis responden cukup tinggi, yaitu $86,11 \%$ memiliki pengetahuan yang tinggi, $100 \%$ memiliki sikap yang tinggi dan $72,22 \%$ memiliki aspek tindakan yang tinggi. Terdapat hubungan antara karakteristik dengan keaktifan mencari informasi. Karakteristik personal yang berhubungan dengan keaktifan mencari informasi melalui tatap muka adalah umur, pendidikan formal, pengalaman usaha, sistem usaha, skala usaha, tujuan pemasaran, keikutsertaan dalam kelompok dan keikutsertaan dalam kemitraan. Sedangkan karakteristik yang berhubungan dengan keaktifan mencari informasi melalui media adalah umur, keterdedahan pada majalah, keterdedahan pada televisi dan sistem usaha. Terdapat hubungan yang rendah antara karakteristik dengan perilaku agribisnis. Karakteristik personal yang berhubungan dengan perilaku agribisnis adalah tingkat pendidikan, sistem usaha, keikutsertaan di dalam kelompok, keterdedahan pada televisi, skala usaha dan tujuan pemasaran. Terdapat hubungan yang rendah antara keaktifan mencari informasi dengan perilaku agribisnis. Variabel keaktifan mencari informasi yang berhubungan dengan perilaku agribisnis adalah keaktifan mencari informasi dengan wakil perusahan tujuan distribusi, yaitu berhubungan pada aspek pengetahuan dan tindakan.

\section{Kendala dalam Mencari Informasi Pertanian}

a. Faktor internal yaitu rasa malas dan kurangnya kesadaran dari mahasiswa untuk mencari informasi pertanian karena kurangnya minat mahasiswa terhadap pertanian. 
Latar Belakang mahasiswa Fakultas Pertanian masuk ke Fakultas Pertanian bukan karena rasa cinta terhadap pertanian. Faktor yang mendorong mahasiswa untuk mencari informasi seputar pertanian adalah karena adanya dorongan dari luar berupa tugas kuliah.

b. Sosialisasi tentang pertanian yang masih terbilang kurang sering dilaksanakan di Fakultas Pertanian

c. Mading tentang informasi pertanian di kampus sebaiknya lebih update dengan informasi kondisi pertanian terbaru berupa informasi pertanian lokal dan informasi pertanian nasional. Selain dalam bentuk cetakan, bisa dengan membuat mading online

d. Masyarakat yang mengembangkan pertanian di daerah Kalimantan masih terbilang kurang dan komoditas yang ada kurang beragam sehingga agak sulit untuk belajar di lapangan. Mahasiswa lebih banyak hanya belajar teori pertanian dan kurang praktik.

e. Kurang aktifnya mahasiswa mencari channel TV dan media cetak yang membahas masalah pertanian.

f. Informasi dalam bentuk buku pertanian di Ruang Baca Fakultas Pertanian kurang mendukung disebabkan koleksi buku yang terbatas, Pengelolaan dan fasilitas yang kurang mendukung seperti tempat duduk untuk membaca, tidak adanya pustakawan, akses ke internet, penyediaan komputer bagi pemakai dengan menyediakan server yang akan melayani pemakai serta untuk mempercepat kebutuhan mendapatkan informasi dan koleksi yang dimiliki Ruang Baca Fakultas Pertanian.

g. Ketidaktahuan mahasiswa akan beragamnya aplikasi pertanian yang khusus untuk mencari informasi pertanian yang sesuai dengan bidang studi masing-masing. Dalam penelitian berjudul Efektivitas Penyebaran Informasi di Bidang Pertanian melalui Perpustakaan Digital (Kasus Pusat Perpustakaan dan Penyebaran Teknologi Pertanian) oleh Maryam dkk (2009) menjelaskan aksesibilitas responden terhadap sumber-sumber informasi tergolong aktif dan tinggi intensitasnya. Intensitas komunikasi yang dilakukan responden melalui komunikasi interaktif, diskusi, media massa, dan karya tulis relatif rendah. Sebagian besar responden berpendapat cukup memuaskan sampai memuaskan terhadap efektivitas penyebaran informasi di bidang pertanian melalui perpustakaan digital pustaka. Karakteristik responden secara umum tidak ada hubungannya dengan efektivitas penyebaran informasi di bidang pertanian melalui perpustakaan digital. Bukan disebabkan berbagai fasilitas responden mencari informasi akan tetapi dikarenakan sebagai mahasiswa umumnya. Perpustakaan adalah salah satu tempat untuk mencari informasi yang dibutuhkan dalam menyelesaikan tugastugas perkuliahannya dan pustaka adalah perpustakaan khusus yang menyediakan koleksi dan informasi yang dibutuhkan mahasiswa yang banyak berkaitan dengan bidang pertanian. 


\section{Kesimpulan}

Penelitian ini menunjukkan bahwa mahasiswa Fakultas Pertanian kurang minat terhadap informasi pertanian dan kurang aktif dalam mencari informasi seputar pertanian . Di sisi lain mahasiswa Fakultas Pertanian sangat membutuhkan informasi pertanian sehubungan dengan kurangnya Mahasiswa Fakultas Pertanian melakukan kontak dengan sumber informasi. Mahasiswa Fakultas Pertanian memerlukan dorongan dan sosialisasi dalam mengakses informasi-informasi terbaru di bidang pertanian, baik yang terdapat dalam media online maupun media cetak.

\section{Daftar Pustaka}

Adhyani A. (2008). Keaktifan Mencari Informasi Dan Perilaku Agribisnis Pembudidaya Ikan Hias Di Kabupaten Bogor. [Skripsi]. Institut Pertanian Bogor.

Andriaty, E., Sankarto, B. S., \& Setyorini, E. (2011). Kajian kebutuhan informasi teknologi pertanian di beberapa kabupaten di Jawa. Jurnal Perpustakaan Pertanian, 20(2), 5461.

Davis, B. (2009). Management information system: conceptual foundation, structure and development (Second Edition). New York: McGraw Hills.

Mardikanto T. (2010). Penyuluhan Pembangunan Pertanian. Surakarta: Sebelas Maret University Press.

Maryam, S., \& Hubeis, M. (2009). Efektivitas Penyebaran Informasi di Bidang Pertanian melalui Perpustakaan Digital (Kasus Pusat Perpustakaan dan Penyebaran Teknologi Pertanian). Jurnal Komunikasi Pembangunan, 7(1).

Prihandoyo, WB. (2014). Efektivitas Diseminasi Informasi Pertanian Melalui Media Telepon Genggam Pada Petani sayuran di Kecamatan Pacet Kabupaten Cianjur. [Tesis]. Sekolah Pascasarjana Institut Pertanian Bogor.

Setiabudi D. (2004). Pemanfaatan Media Informasi Teknologi Pertanian Oleh Penyuluh Pertanian Di Jakarta. [Tesis]. Bogor: Sekolah Pascasarjana Institut Pertanian Bogor.

Silalahi, Ulber. (2015). Metode Penelitian Sosial Kuantitatif. Bandung: Refika Aditama.

Slameto. (2010). Belajar dan Faktor-faktor yang Mempengaruhi. Jakarta: PT. Rineka Cipta.

Sugiyono. (2010). Metode Penelitian Kuantitatif Kualitatif dan R\&D. Bandung: Alfabeta

Wilson, T. D. (2000). Human information behavior. Informing Science: the International Journal of an Emerging Transdiscipline, 3, 49-56. 